\title{
Pre and Post MCCG 2017: Board Audit Committee Effectiveness and Independence Issues
}

\author{
Dayana Mastura Baharudin \\ Department of Accounting, School of Management, Universiti Sains Malaysia \\ Penang, 11800, Malaysia \\ E-mail: dayana.mastura@usm.my
}

Received: October 8, 2019 Accepted: November 2, 2019 Published: November 6, 2019

doi:10.5296/bms.v10i2.15578ＵRL: https://doi.org/10.5296/bms.v10i2.15578

\begin{abstract}
Purpose - This study investigates the impact of the two main issues of the fortification of the Board Audit Committee which includes the effectiveness and independence factors practiced within the Audit Committee compared between the era of MCCG 2012 and MCCG 2017.

Design/methodology/approach -In order to review the performance of active and distinct Board Audit Committees, purposeful sampling approach is used, accompanied with regression analysis, content analysis, and systematic prior research, which evaluates the Annual Reports, Sustainability Reports and Integrated Reports.

Originality/value - This study is a systematic review of recent research developments in MCCG 2012 and MCCG 2017. The Effective Board Audit Committee and the Independent Board Audit Committee scoring indices designed could also be applied to other PLCs other than those within the Malaysian oil and gas industry.

Keywords: Malaysian Code of Corporate Governance, MCCG 2012, MCCG 2017, Board Audit Committee, Malaysian oil and gas industry.

\section{Introduction}

The role of the Board Audit Committee has been criticized significantly due to the infamous prior large corporate scandals of WorldCom and Enron in 2002. The auditor in question was Arthur Anderson, the external auditor for both WorldCom and Enron which also collapsed after the corporate scandal as they failed to perform their fiduciary duties as a good external
\end{abstract}


auditor but even so, the Board Audit Committee of Enron and WorldCom should have probed on highlighted issues from the external auditor, internal auditor and from their top management collectively. The major problems here could be that either the Board Audit Committee lacked certain accounting and audit skills or they were in it together with Arthur Anderson and the rest of the board members together with the C-suite in committing a financial crime which was one of the largest globally at the time.

The top management and the board are highly pressured to produce high earnings for the shareholders which in turn could lead to the activities of earnings management in order to benefit the board and the top management team as they believed that they should be highly rewarded rather than the shareholders.

Looking as far as the United States Securities and Exchange Commission (SEC) back in 1998 before the Enron and WorldCom debacle in 2002, the Chairman, Mr. Levitt was genuinely concerned with the earnings management activities conducted by the board and top management and called for restructuring of the corporate governance rules focused on the role of the Board Audit Committee specifically. This is because the Board Audit Committee had the role of being the last point of fraud detection, control and action after the audit fiduciary duties conducted by the external and independent auditors.

Therefore, the SEC launched the Blue-Ribbon Commission in Improving the Efficacy of Corporate Audit Committees in 1999 which included 10 guidance rules (Blue Ribbon Commission, 1999). However, this was before the Enron and WorldCom corporate scandals which rocked corporate America and the world at a very large scale and should this BRC guidance was taken up seriously by the public listed companies on the New York Stock Exchange back then, the author is revelling in the fact that the legendary Enron, WorldCom and Arthur Andersen collapse would never have occurred.

The BRC required the Board Audit Committees to furnish the SEC with a copy of their activities together with the composition of the Board, together with the Charter of the Board Audit Committee for the financial year ended on or after 15 December 2000 (SEC, 1999). These reports supposedly would protect the shareholders and stakeholders as the SEC would be highly informed on the performance and integrity of the Board Audit Committee.

Therefore, the author would like to highlight the following problems within this area of study identified, which are discussed below.

The role of the Board Audit Committee has been under scrutiny and under fire based on the recent financial scandals that have destroyed the trust towards the global financial institutions even after the best practice recommendations by the financial regulators namely the SEC. This is because the last point of inspection of the financial statements after the honest and trustworthy external auditors performed their last scrutiny would be the Board Audit Committee. Further pressing issues could be either that the board composition does not comprise of independent directors or the presence of directors without sound financial knowledge and experience namely the experience required of a Chartered Accountant are on 
board the Audit Committee.

Previous studies also focused on the features of audit committees in assessing their efficacy (DeZoort et al., 2002). Abbott et al. (2004) found that the Independent Audit Committee, which operates at least four times a year and includes at least one member with financial expertise, had a negative impact on the rate of financial restatements in the era of 1991-1998.

Most of the previous research was focused on the Independent Directors within the Board Audit Committee of the companies listed on the global stock exchanges. General expectations are that there should be better financial disclosure by independent directors residing on the audit committee which was not clearly evident (SEC, 1999).

The BRC (1999) and the SEC (1999) requires that the Board Audit Committees must comprise of at least four directors to prevent earnings management but Xie et al. (2003) noticed that there was no significant correlation between the number of directors residing within the audit committee and earnings management. Likewise, Abbott et al. (2004) observed little impact on the reassessment of profits on the number of directors residing within the audit committee. Alternatively, Yang and Krishnan (2005) found that the size of the Board Audit Committee is adversely correlated with earnings management (using excessive accrual as proxy), indicating that the quality of financial statements may require a minimum number of directors to reside within the Board Audit Committee to probe and challenge the current situation.

The 1997 currency crisis in Malaysia was branded as one of the worst economic crisis that the nation has experienced which have exposed serious weaknesses in the current corporate governance policy and procedures, including poor financial management, corporate over-borrowing, lack of transparency in the disclosure of the annual reports, and lack of accountability by the board members and top management towards the shareholders.

The release of the Malaysian Corporate Governance Code 2000 and the Bursa Malaysia Revamped Listing Requirement 2001 underlines the importance of corporate governance and disclosure requirements in which the independent directors should be assigned to the audit committee as a precautionary measure.

The need to establish an audit committee consisting of at least three independent directors is designed to improve the regulatory activities of the board, increase investor confidence and increase transparency and accountability of financial information provided by listed companies.

Therefore, the emphasis of this study is on gaining an understanding of whether the presence of a corporate governance policy in terms of board composition which reflects the independence and effectiveness of the board of directors on the audit committees, will lead to firm financial performance of the Malaysian public listed firms.

Malaysia is of concern because it is a developing country with an increasing capital market unlike the Anglo-Saxon world's scattered shareholding, Malaysia is distinguished by 
centralized shareholding. Many of the public listed businesses in Malaysia are family owned or controlled, with many companies arising from traditional family-owned small private owned businesses representing different cultural practices and aspirations (Claessens et al., 2000).

Therefore, this study has identified three research objectives to be achieved within this course of study as follows:

1. To measure the discrepancy of the disclosure level between the Corporate Governance policy in 2012 and 2017 on the Effective and Independent Board Audit Committee within the Malaysian petroleum industry

2. To investigate the impact of the disclosure extent of the Effective Board Audit Committee compared between the Corporate Governance policy in 2012 and 2017 towards the financial performance of the Malaysian petroleum industry

3. To examine the impact of the disclosure extent of the Independent Board Audit Committee compared between the Corporate Governance policy in 2012 and 2017 towards the financial performance of the Malaysian petroleum industry

Furthermore, this study has also established the following research questions to be answered within this research as follows:

1. What is the disclosure level of Effective and Independent Board Audit Committee during the era of the Corporate Governance policy in 2012 and 2017 which reflects the implementation level?

2. Does the disclosure extent of the Effective Board Audit Committee have impact on the financial performance of the Malaysian petroleum industry when comparing the Corporate Governance policy of 2012 and 2017?

3. Does the disclosure extent of the Independent Board Audit Committee have impact on the financial performance of the Malaysian petroleum industry when comparing the Corporate Governance policy of 2012 and 2017 ?

\section{Prior Research Deliberations}

Bursa Malaysia (formerly known as the Kuala Lumpur Stock Exchange) has been mandated since 1 August 1994 to set up an audit committee within Malaysia's publicly listed firms. However, the Code of Corporate Governance states that the audit committee should be made up of at least three members, while its leader should be a non-executive director.

A report by Muhamad Sori et al. (2001) found that the Chair of the Malaysian audit committee perceives the committee as having an effective role in managing audit and financial functions. Consequently, Vicknair et al. (1993) proposed that, in order to operate efficiently, audit committees must be autonomous from leadership, and to remain free from undue influence or corporate executive interference. 
However, several observational findings typically indicate that the audit committee independence is found to be not only adversely related to the occurrence of financial misconduct (Beasley, 1996; Dechow et al., 1995); (Xie et al., 2003) and adversely correlated towards misleading or fraudulent disclosure (Abbot and Parker, 2000), and also negatively correlated towards financial performance (Felo et al., 2003).

Choi et al. (2004) also observed that members of the Audit Committee are less inclined if they own shares in the company to escape earnings management. Furthermore, Felo et al (2003) observed that the audit committee members with accounting and financial management expertise were positively correlated with the quality of financial reporting.

Bursa Malaysia listing requirements also stipulates that a member of the Malaysian Institute of Accountants (MIA), namely a Chartered Accountant must be a representative within the audit committee who must have relevant expertise, experience and training (Bursa Malaysia, 2017). The 2012 Malaysian Corporate Governance Code (MCCG 2012) has recognised the functions of the Audit Committee by Principle 5: Uphold Transparency in Financial Reporting, in which the Audit Committee must guarantee that the financial statements conform with the financial reporting standards in force in Recommendation 5.1. Among other factors, the Audit Committee must ensure that the financial statements of the company meet with the applicable financial reporting standards as an integral part of the credibility of the financial statements (Securities Commission, 2012).

Additionally, the Audit Committee should have policies and procedures as per Recommendation 5.2 to assess the suitability and independence of external auditors. The audit committee will assess and track the suitability and integrity of independent auditors. The discretion of external auditors may be compromised by supplying the client with non-auditing services (Securities Commission, 2012).

To endorse a commitment of autonomy, the Audit Committee must be provided a formal confirmation from the external auditors that they are and have been impartial throughout the audit undertaking and implementation, in compliance with all relevant professional and regulatory requirements (Securities Commission, 2012).

Under Principle B: Good Inspection and Risk Management, in MCCG 2017, there were recommendations of best practice that were a step-up from the previous MCCG 2012. An effective audit committee can provide transparency, financial reporting process clarity, and impartial analysis. Nevertheless, the whole management team is largely responsible for a corporation's financial reporting system.

The review panel plays a crucial role in a corporate governance framework. The independent Audit Committee will further examine and present detailed probing questions about the company's financial reporting, internal controls, risk management and governance processes.

The quality of the deliberations of the Audit Committee can be greatly enhanced by a strong understanding of the financial reporting process, complemented by a wide range of different perspectives (Securities Commission, 2017). MCCG 2017 proposes best practice 
recommendations in Practice note 8.1 in which the Chair of the Audit Committee is not the Chairman of the Board of Management.

Practice notice 8.2 of MCCG 2017- The Audit Committee shall have a policy requiring a new principal audit associate to observe a cooling-off period of at least two years before resuming work with the Audit Committee. The Audit Committee shall provide policies and procedures for evaluating the suitability, objectivity and discretion of the independent external auditor.

A step-up recommendation within MCCG 2017 would be Practice Note 8.4 where only Independent Directors are allowed to join the Audit Committee (Securities Commission, 2017). Practice Note 8.5 of MCCG 2017 notes that the Audit Committee should jointly have a wide range of competencies necessary to perform its duties.

Members of the Audit Committee must undertake continuing professional development (CPD) to keep abreast of new changes in accounting and auditing standards, practices and legislation (Securities Commission, 2017).

\section{Underpinning Theory}

\section{Agency Theory}

Based on the agency theory, issues related to the ownership and control division will drive executives (agents) to operate opportunistically by increasing their own wealth at the expense of the company's shareholders (principals) (Jensen and Meckling, 1976). Since financial statements can provide valuable information to the company's external parties, management may exploit the financial statements to their own benefits at the expense of the shareholder's wealth.

The incentives of managers to monitor reported earnings may be influenced by job security, contractual agreements between management and shareholders, self-interest in the existence of reward systems or the need to meet goal earnings or even market expectations (Healy and Wahlen, 1999). The philosophy of the company supports the idea that boards should be managed by independent directors to optimize the independence of the audit committee from the management.

One of the explanation is that non-executive directors are expected to monitor and control the activities of executive directors whose conduct were likened to be "opportunistic" (Jensen and Meckling, 1976). Such non-executive directors' presence may affect the quality of the executive directors' meetings and decisions, provide strategic direction and enhance performance (Zahra and Pearce, 1989), thus ensuring that management behaves responsibly and in the best interests of both shareholders and stakeholders.

\section{Lens Theory}

\section{Resource Dependency Theory}

The concept of asset dependence characterizes the enterprise as an open system based on external contingencies (Pfeffer \& Salancik, 1978). 


\section{Macrothink Institute ${ }^{\text {TM }}$}

Resource Dependency Theory acknowledges the effect of external factors on organizational behavior, and managers must work to reduce environmental instability and dependency while being constrained by context. For these acts, the notion of power, which is management of vital resources, is central (Ulrich \& Barney, 1984). Organizations try to diminish certain people's power on them, frequently trying to maximize their own leverage over others.

Because of their expertise, credibility and relationships, the asset dependency hypothesis often advocates for more non-executive directors on board (Kesner and Johnson, 1990). Nevertheless, many researchers consider the risks of having a high number of non-executive directors on the board may constraint the creativity of ideas.

These shortcomings of having too many non-executives on board include stifling strategic conduct (Goodstein et al., 1994), excessive command (Baysinger and Butler, 1985), lack of efficient business experience (Patton and Baker, 1987) and lack of genuine independence (Demb and Neubauer, 1992).

\section{Research Framework}

Board Audit Committee issues $\quad$ Firm financial performance

IVI

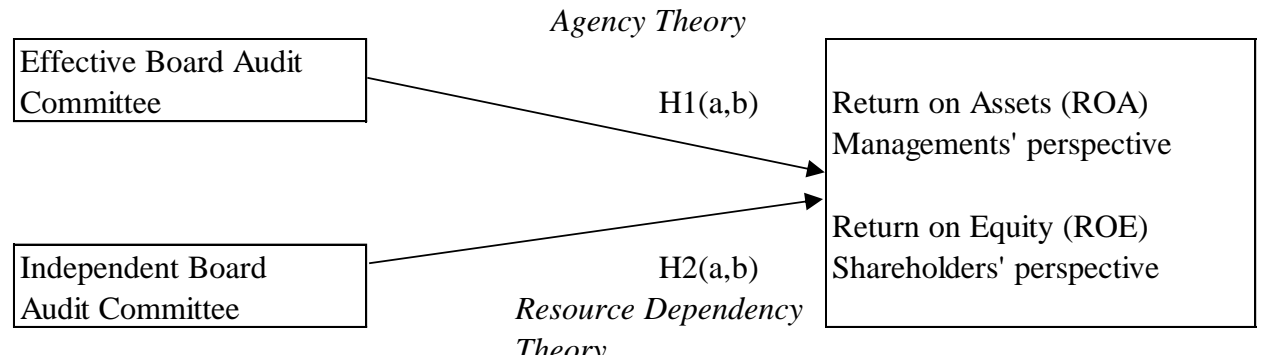

Theory

Independent Variables

Dependent Variable

Controlled Variables

Firm Age

Firm Size

Figure 1. Research Framework

\section{Return on Equity and Return on Assets as proxies for Firm Financial Performance}

Return on equity implies the net profit is split into the book value of the investor to determine how much the company produces for its investors. The investment capital of the company typically contains the amount of assets which shareholders may reach (Richard, Devinney, Yip, and Johnson, 2009). Prior literature includes various indicators such as: investment returns, capital returns (Huang, Oua, Chena, \& Lin, 2006; Khanna \& Palepu, 2000; debt 
returns, 2000), Tobin's Q (Habib \& Ljungqvist, 2005; Khanna \& Palepu, 2000).Indicators such as resource returns and stock returns are accounting-based performance indices.

Accounting-based measures represent recent economic results when future performance is measured by market-based measurements. When return on capital was used as a metric of the company's performance, it would simply demonstrate how well the company uses its resources to generate revenue.

To generate higher profits for shareholders to satisfy, the business should invest in assets other than debt. This can promote the use of return on equity as a powerful performance metric. Companies can artificially use economic strategies to maintain a good return on equity for a while and to cover deteriorating corporate fundamental output.

Considering the reduction in operating profits, increased debt leverages and buybacks financed by excess assets may help maintain the ROE of the business. Depending on their balance sheet and other financial statements, the return on investment and return on equity are measured and are therefore not market-based variables. The balance sheet statements could also have an effect on bond policies based on portfolio assumptions (Chaudhuri, Kumbhakar, and Sundaram 2016).

The following four hypotheses 1(a), 1(b), 2(a) and 2(b) are identified for this study:

Hypothesis 1(a): Effective Board Audit Committee has positive impact on firm performance during the enforcement period of the policy of Corporate Governance Code of 2012

Hypothesis 1(b): Effective Board Audit Committee has positive impact on firm performance during the enforcement period of the policy of Corporate Governance Code of 2017

Hypothesis 2(a): Independent Board Audit Committee has positive impact on firm performance during the enforcement period of the policy of Corporate Governance Code of 2012

Hypothesis 2(b): Independent Board Audit Committee has positive impact on firm performance during the enforcement period of the policy of Corporate Governance Code of 2017

\section{Regression Analysis Models}

The following regression models are proposed to test the variables under study:

\section{Regression Model 1:}

$\mathrm{RE}=\beta 0+\beta 1 \mathrm{EBAC}+\beta 2 \mathrm{IBAC}+$ eit

Where

$\mathrm{RE}=$ Return on Equity for measuring accounting performance of the Malaysian petroleum industry 


\section{Macrothink}

$\mathrm{RA}=$ Return on Assets for measuring accounting performance of the Malaysian petroleum industry

$\mathrm{EBAC}=$ Effective Board Audit Committee

IBAC $=$ Independent Board Audit Committee

cit $=$ Error term

\section{Regression Model 2:}

$\mathrm{RA}=\boldsymbol{\beta 0}+\beta 1 \mathrm{EBAC}+\beta 2 \mathrm{IBAC}+$ sit

\section{Research Methodology}

The public companies issuing Integrated Reports on Bursa Malaysia from a total of 887 Malaysian PLCs will be scrutinized in this research study in which from 2016 to 2018, the information will be collected accordingly. This study suggests a focused sample of 33 publicly listed petroleum companies on Bursa Malaysia.

In the review of the prior comprehensive articles, the study requires descriptive statistics, correlation analysis and content analysis as, the Code in 2012 is still effective and established, to monitor the results, in year 2016. The year of 2017 will be selected as the new Code was launched in 2017 and companies are in transition from the policies of the Code in 2012 to the policies of the Code in 2017, in which the improvements introduced in the Code in 2017 are most likely to not be implemented yet as organisations have to consider the cost of implementation of a new Code together with the fact that the employees would not have sufficient governance training to implement the new Code.

As a result of the changes made in MCCG 2017, year 2018 will be selected to consider the effect of the planned implementation of the new code. During these three years, the author will be able to analyse the trend between pre- and post-effects of MCCG 2017.

The most widely used and prominent method of study of corporate reporting is content analysis (Shadi and Ghazali, 2015; Boesso and Kumar, 2007). In the content analysis, qualitative and quantitative analysis can be done. The most accurate data analysis is known to be the quantitative material assessment (Zahid and Ghazali, 2015; Day and Woodward, 2009). The data classification by content analysis approach would be based on topics, words or components (Nilsson, 2016; Collins and Hussey, 2014). Throughout identification process, the rating system is used to determine the extent to which items are marked as significant.

Table 1 and Table 2 below shows the items obtained from the Code in 2017 to reflect the tightening of the governance policy from 2012 to 2017. 
Table 1. A New Effective Board Audit Committee Scoring Index

\section{Effective Board Audit Committee}

* Former key audit partner to observe a cooling-off period of at least two years before being appointed as a member of the Audit Committee

* The Audit Committee has policies and procedures to assess the suitability, objectivity and independence of the external auditor

Table 2. A New Independent Board Audit Committee Scoring Index

\section{Independent Board Audit Committee}

* The Chairman of the Audit Committee is not the Chairman of the Board

* The Audit Committee should comprise solely of Independent Directors

\section{Practical Significance}

This research is one of the first in comparative analysis of the Malaysian Corporate Governance policy launched in 2012 and 2017 in order to determine the effectiveness and implementation of the new Code despite the tightening of rules and regulations over the 5-year period.

The Malaysian petroleum industry can be considered as a global hub for oil and gas multinational companies from around the world. Foreign multinationals operating in oil and gas has major interest in being domiciled in Malaysia. This is due to a number of factors which includes having a high number of trained oil and gas professionals across Malaysia, the quality of English speaking professionals, the presence of a Forbes Fortune 500 National Oil Company which is owned by the Malaysian government and founded in 1974 ranked within the Top 100 recently, namely Petronas with its wholly owned university which just celebrated its $20^{\text {th }}$ anniversary recently, Universiti Teknologi Petronas which has produced thousands of oil and gas graduates at the degree, masters and $\mathrm{PhD}$ level for the past 20 years. All this could not be jeopardized by the lack of corporate governance especially for the Malaysian petroleum industry operating on global terms.

This study is important for listed public entities since it helps annual report preparers understand the difference between the Code in 2012 and the Code in 2017 and the need to make changes when preparing the Annual Reports, Sustainability Reports or Integrated Reports.

The essence of corporate reporting actually lies in the actual implementation and actual practice within the organisations itself. Therefore, if companies are not able to implement the 
new Code in 2017, then there would much difficulty in disclosing the results and activities from the Code in 2017 within the corporate reports.

Companies therefore could use the new indices in Table 1 and 2 to measure the independence and effectiveness of their current Board Audit Committee as there are obvious benefits to be accrued from implementing the new Code in 2017 with respect to the Board Audit Committee characteristics.

\section{Discussion and Suggestion for Future Research}

The ultimate responsibility of the financial reporting process lies within the full board of directors; however, the Board Audit Committee despite being only a sub-committee of the Board of Directors has a pivotal role in the overall company governance structure and should take the lead to rigorously challenge and probe on the organisation's financial reporting process, internal controls and the risk management procedures. It is important that the Board Audit Committee remains independent to carry out its role objectively coupled with the high level of financial knowledge and literacy, skills, experience, commitment and have undertaken relevant continuous professional development (CPD) in order to keep abreast of the recent relevant developments in their respective industry and the financial arena.

Future research could look into the role of the Chairman of the Audit Committee in ensuring the effectiveness and independence issues as discussed within this study. Since 2012 the Code recommended that the role of the Chairman of the Board and the role of the Chairman of the Audit Committee cannot be in the hands of the same individual to remain objective in assessing the findings related to the overall financial activities of the organisation.

Further research could also look into the line of reporting and the sequence of reporting of findings from the external auditor to the Board Audit Committee and vice versa, as the governance rules require that should external auditors find questionable evidence that relates to the work of the Chief Financial Officer (CFO) and Chief Executive Officer (CEO), then it should be communicated to the Board Audit Committee immediately to take action. Therefore, the main critical roles that could control or jeopardize the company would be the CEO, CFO, Internal Auditors, External Auditors, the Board Audit Committee, the Chairman of the Board Audit Committee and the Chairman of the Board. In the case of Enron and WorldCom back in 2002, all of these parties have colluded together to commit one of the largest financial scandal globally which results in the failure of corporate governance as the points of checks and controls have all failed. There would be a need to create another governance role but that could also prove not to be effective once it goes into practice.

\section{References}

Abbott, L. J., Park, Y., \& Parker, S. (2000). The effects of audit committee activity and independence on corporate fraud. Managerial Finance, 26(11), 55-68. https://doi.org/10.1108/03074350010766990

Abbott, L. J., Parker, S., \& Peters, G. F. (2004). Audit committee characteristics and 
restatements. Auditing: A Journal of Practice \& Theory, 23(1), 69-87. https://doi.org/10.2308/aud.2004.23.1.69

Arens, A., Elder, R., \& Beasley, M. (2003). Auditing and Assurance Services: An Integrated Approach, 9th ed., Prentice-Hall, Englewood Cliffs, NJ.

Beasley, M. S. (1996). An empirical analysis of the relation between the board of director composition and financial statement fraud. Accounting review, 443-465.

Beasley, M. S., Carcello, J. V., Hermanson, D. R., \& Lapides, P. D. (2000). Fraudulent financial reporting: Consideration of industry traits and corporate governance mechanisms. Accounting Horizons, 14(4), 441-454. https://doi.org/10.2308/acch.2000.14.4.441

Beck, P. J., Frecka, T. J., \& Solomon, I. (1988). An empirical analysis of the relationship between MAS involvement and auditor tenure: Implications for auditor independence. Journal of Accounting literature, 7(1), 65-84.

Becker, C. L., DeFond, M. L., Jiambalvo, J., \& Subramanyam, K. R. (1998). The effect of audit quality on earnings management. Contemporary accounting research, 15(1), 1-24. https://doi.org/10.1111/j.1911-3846.1998.tb00547.x

Bédard, J., Chtourou, S. M., \& Courteau, L. (2004). The effect of audit committee expertise, independence, and activity on aggressive earnings management. Auditing: A Journal of Practice \& Theory, 23(2), 13-35. https://doi.org/10.2308/aud.2004.23.2.13

Bernard, V. L., \& Skinner, D. J. (1996). What motivates managers' choice of discretionary accruals?. Journal of Accounting and Economics, 22(1-3), 313-325. https://doi.org/10.1016/S0165-4101(96)00431-4

Blue Ribbon Committee on Improving the Effectiveness of Corporate Audit Committees. (1999). Report and recommendations of the Blue Ribbon Committee on improving the effectiveness of corporate audit committees. The Business Lawyer, 1067-1095.

DeAngelo, H., DeAngelo, L., \& Skinner, D. J. (1994). Accounting choice in troubled companies. Journal of accounting and economics, 17(1-2), 113-143. https://doi.org/10.1016/0165-4101(94)90007-8

Dechow, P. M., \& Dichev, I. D. (2002). The quality of accruals and earnings: The role of accrual estimation errors. The accounting review, 77(s-1), 35-59. https://doi.org/10.2308/accr.2002.77.s-1.35

Dechow, P. M., Sloan, R. G., \& Sweeney, A. P. (1995). Detecting earnings management. Accounting review, 193-225.

DeZoort, F. T., \& Salterio, S. E. (2001). The effects of corporate governance experience and financial-reporting and audit knowledge on audit committee members' judgments. Auditing: A Journal of Practice \& Theory, 20(2), 31-47. https://doi.org/10.2308/aud.2001.20.2.31 
DeZoort, F. T., Hermanson, D. R., Archambeault, D. S., \& Reed, S. A. (2002). Audit committee effectiveness: A synthesis of the empirical audit committee literature. Audit Committee Effectiveness: A Synthesis of the Empirical Audit Committee Literature, 21, 38.

Francis, J. R., Maydew, E. L., \& Sparks, H. C. (1999). The role of Big 6 auditors in the credible reporting of accruals. Auditing: a Journal of Practice \& theory, 18(2), 17-34. https://doi.org/10.2308/aud.1999.18.2.17

Frankel, R. M., Johnson, M. F., \& Nelson, K. K. (2002). The relation between auditors' fees for nonaudit services and earnings management. The accounting review, 77(s-1), 71-105. https://doi.org/10.2308/accr.2002.77.s-1.71

Guay, W. R., Kothari, S. P., \& Watts, R. L. (1996). A market-based evaluation of discretionary accrual models. Journal of accounting research, 34, 83-105. https://doi.org/10.2307/2491427

Healy, P. M., \& Wahlen, J. M. (1999). A review of the earnings management literature and its implications for standard setting. Accounting horizons, 13(4), 365-383. https://doi.org/10.2308/acch.1999.13.4.365

Klein, A. (2002). Audit committee, board of director characteristics, and earnings management. Journal of accounting and economics, 33(3), 375-400. https://doi.org/10.1016/S0165-4101(02)00059-9

Levitt Jr, A. (1998). The numbers game. The CPA Journal, 68(12), 14.

Li, J., \& Lin, J. W. (2005). The relation between earnings management and audit quality. Journal of Accounting and Finance Research, 13(1), 1-11.

Lys, T., \& Watts, R. L. (1994). Lawsuits against auditors. Journal of accounting research, 32, 65-93. https://doi.org/10.2307/2491440

Matsumoto, D. A. (2002). Management's incentives to avoid negative earnings surprises. The accounting review, 77(3), 483-514. https://doi.org/10.2308/accr.2002.77.3.483

McNichols, M. F. (2000). Research design issues in earnings management studies. Journal of $\begin{array}{llll}\text { accounting } \quad \text { and } & \text { policy, 313-345. }\end{array}$ https://doi.org/10.1016/S0278-4254(00)00018-1

Menon, K., \& Williams, J. D. (1994). The use of audit committees for monitoring. Journal of accounting and public policy, 13(2), 121-139. https://doi.org/10.1016/0278-4254(94)90016-7

Millstein, I. M. (2002). Oversight hearing on accounting and investor protection issues raised by Enron and other public companies. US Senate Committee on Banking, Housing, and Urban Affairs, Washington, DC, available at: http://banking.senate.gov/02_02hrg/022702/ millstn.htm

Owers, J. E., Lin, C. M., \& Rogers, R. C. (2002). The informational content and valuation ramifications of earnings restatements. International Business \& Economics Research 
Journal (IBER), 1(5). https://doi.org/10.19030/iber.v1i5.3926

Palmrose, Z. V., \& Scholz, S. (2002). Accounting causes and litigation consequences of restatements. University of Southern California Working Paper.

Palmrose, Z. V., Richardson, V. J., \& Scholz, S. (2004). Determinants of market reactions to restatement announcements. Journal of accounting and economics, 37(1), 59-89. https://doi.org/10.1016/j.jacceco.2003.06.003

Richardson, S. A., Tuna, A., \& Wu, M. (2002). Predicting earnings management: The case of earnings restatements. Available at SSRN 338681. https://doi.org/10.2139/ssrn.338681

Schipper, K. (1989). Commentary on earnings management", Accounting Horizons, Vol. 3, pp. 91-102. SEC (1999), Audit Committee Disclosure, Securities and Exchange Commission, US Government Printing Office, Washington, DC.

Xie, B., Davidson III, W. N., \& DaDalt, P. J. (2003). Earnings management and corporate governance: the role of the board and the audit committee. Journal of corporate finance, $9(3)$, 295-316. https://doi.org/10.1016/S0929-1199(02)00006-8

Yang, J. S., \& Krishnan, J. (2005). Audit committees and quarterly earnings management. $\begin{array}{llll}\text { International of journal auditing, } & \text { 9(3), }\end{array}$ https://doi.org/10.1111/j.1099-1123.2005.00278.x

\section{Copyright}

Copyright for this article is retained by the author(s), with first publication rights granted to the journal.

This is an open-access article distributed under the terms and conditions of the Creative Commons Attribution license (http://creativecommons.org/licenses/by/4.0/). 